\title{
3 The Church in Colombia and extractives: pastoral accompaniment using an eco-theology of peace ${ }^{1}$
}

\author{
Sandra Polanía-Reyes and \\ Héctor Fabio Henao
}

This chapter describes and analyzes the interaction between conflict, extractives, and institutions at the intersection of civic participation and pastoral accompaniment in Colombia. For generations, mining has been part of life for many Colombians. After the 2016 accord, many, including the government, counted on mining to deliver a peace dividend. In an effort to accompany local communities, the Catholic Church has responded in a variety of ways to challenges posed by mining.

This study maps and analyzes that church response. The first section describes the current socio-political context of Colombia. After an internal social and armed conflict of more than six decades, the country is going through a phase of peace implementation and restoration, and faces challenges and coordination failures involving the current government, economic actors, and civil society. The second section addresses Colombia's legacy of mining and the trade-off between conservation and extractivedependent development in a country with a large degree of biodiversity, a fraught history of violent conflict and social inequity, and large amounts of non-renewable resources.

The third section presents a national survey of all ecclesiastical jurisdictions examining the dynamics and impacts of mining, and the responses of civil society and the Catholic Church. It provides valuable data on the extent of mining that is not readily available from the government and other sources. A baseline was conducted in 2013 and a follow-up in 2020. The timeline allows us to analyze changes related to the national peace agreement of 2016. We find a major increase in mining throughout Colombia since 2013. Moreover, the social, environmental, economic, and cultural impacts of mining on communities have worsened. The fourth section analyzes the church's response to the challenges of mining and describes the resources and tools it has used when accompanying communities in reconciling mining, integral human development, and peace. We complement this section with reflections on how the church's response could be improved.

DOI: $10.4324 / 9781003094272-3$ 


\section{The socio-political context for pastoral accompaniment on mining}

Colombia is framed by a great contrast between positive macroeconomic growth and an internal social and armed conflict of more than six decades. The presence of illegal armed actors, both of the extreme left and right wings, has generated a deep humanitarian crisis with more than nine million registered victims. In a country of 48 million inhabitants, this means that $18 \%$ of the total population of Colombia has been victims of the internal armed conflict, with the social, economic, and cultural consequences that this entails. The humanitarian crisis has also been worsened by the Venezuelan diaspora, which adds uncertainty and unrest (see Colombian Ministry of Foreign Affairs 2021).

The Catholic Church's pastoral accompaniment in Colombia takes place amidst one of the most complex and lengthy conflicts in the world. Two attempts in recent years to end the conflict have faced major difficulties. First, the negotiation process with the guerrillas of the National Liberation Army (ELN) that began in March of 2016 failed due to a terrorist act committed in Bogotá in January of 2019. Though the COVID-19 pandemic has renewed interest in a possible peace, formal peace talks have not resumed. Second, the 2016 Peace Agreement with the Revolutionary Armed Forces of Colombia (FARC) ended a five-decade conflict. However, there has been growing disapproval of the peace process by the current government and implementation of the agreement has been difficult. At the end of the fourth year of implementation, only $28 \%$ of stipulations have been fully implemented, $18 \%$ of stipulations are at an intermediate level of progress, and $54 \%$ of commitments have either begun but made marginal progress, or have yet to be initiated (Peace Accords Matrix Barometer Initiative 2021). The slow implementation has allowed illegal armed groups to reemerge in former FARC territories.

There are disputes over territory today between guerrillas, drug traffickers, paramilitaries, and other illegal armed actors who aim to defend their economic and political interests. These interests collide with the government's and are generally tied to drug trafficking and the legalization of mega-economic projects, such as mining, extraction of natural resources, agro-industry, extensive livestock farming, monocultures, and generation of electric power, in which the land and the abundant natural resources become strategic targets for national and transnational actors. These disputes increase human rights and international humanitarian law violations, as well as forced displacement, in most rural territories.

In particular, Colombia is the most dangerous country in Latin America for social leaders (UN Human Rights Council 2019, sec. 20). Human Rights Watch reports that between 2016 and February 2021 four hundred human rights defenders were killed (Cuartas 2021), although some sources report higher numbers. ${ }^{2}$ Besides these assassinations, there have also been 
numerous cases of threats, displacement and confinement, robberies, kidnappings, attempted killings, sexual violence, disappearances, and confrontations. Most of the indigenous Afro-Colombian communities and campesinos who suffer the attacks are in areas where mining is prevalent.

\section{The legacy of mining in Colombia}

Mining in Colombia must be understood in the context of immense biodiversity. The country occupies $0.7 \%$ of the world's continental surface and has $10 \%$ of the world's biodiversity. But today, half of Colombia's ecosystems are critically threatened, and a third of its plants and half of its animals are under threat from habitat loss due to oil, mineral, and metal extraction, deforestation, extensive cattle-ranching, generation of electric power, wildlife trafficking, and the impact of the coca trade, among others.

Mining is the means of subsistence for a large number of Colombians. About six million people live in areas where mining occurs. The prominence of mining extends back far before the colonial era, and was a central aspect of the colonial program. Mining, including the abuses it brought and the problems that it left behind, is an irrevocable part of the nation's heritage, although the role it continues to play in the country's economic development is tremendously complicated. Violence and conflict, environmental degradation, and social injustice swirl around the industry.

Before the arrival of the Spaniards, indigenous people engaged in agriculture and in artisanal mining, especially of gold. These activities were part of their culture and tradition. After the conquest, the extraction of gold and silver intensified and became a way for indigenous peoples to participate in commercial exchange. By the nineteenth century, the country had the most mining activity in Latin America. But by the 1950s the low prices of precious minerals worldwide and the internal armed conflict caused mining activity to decrease to the point that by 1980 there were only two large national mining companies still in operation: Cerrejón and Cerro Matoso.

However, the oil and mining boom at the end of the 1980s and the beginning of the 1990s reactivated Colombia's extractive industries. In the last two decades, extractive industries have had so much support that the Uribe government (2002-2010) granted 8.53 million hectares, a territory the size of Austria, for exploitation. During the Santos government (2010-2018), mining became one of the five pillars of national development, which prompted a strong campaign to attract foreign investment through regulatory easing. However, this model is based on only the extraction of raw materials, without generating any added benefit to the communities or the environment. Other sectors have raised the alarm that economic growth of extractives without technological innovation or the generation of new industries will jeopardize Colombia's economy in the long term. 
Today, there are three types of mining in the country: small-scale traditional or artisanal, medium-scale, and industrial or large-scale. Small-scale traditional mining has been used by indigenous cultures since ancient times and is also used by miners settled in small towns, some of whom are displaced. Although artisanal mining can frequently have serious negative consequences for the environment, a cooperative of ethnic communities in Choco called Oro Verde promotes use of a technique traditionally called "mazamorreo" or "barequeo" to extract gold, silver, platinum, or other minerals by hand, and the cooperative became a global pioneer in the movement for ecologically friendly artisanal mining. Oro Verde was credited as an inspiration for the global Alliance for Responsible Mining that promotes socially responsible and environmentally sustainable artisanal mining practices (Alliance for Responsible Mining 2014).

Medium mining uses some heavy equipment, like dredgers and backhoes, which allows greater productivity but has a greater environmental impact. That impact is made worse in some cases because of irregularities in the procedures and extraction processes and lack of compliance with national regulations. This type is important to illegal armed actors, especially in the areas of the Pacific and the Amazon, where they create alliances with national or foreign miners (Peruvians and Brazilians) to extract gold and wood in a disorderly and illegal manner. Several reports have documented that $80 \%$ of the mining in the country is illegal, and $60 \%$ of the illegal mining is in protected areas. This is due to the shortcomings of environmental licensing, the inefficient management of local governmental offices, and ineffective enforcement actions.

Large-scale mining, which is associated with megaprojects, is the type carried out by multinationals that benefit from favorable legislation and fiscal policies. These projects have a corporate social responsibility component, though that usually does not compensate for environmental damages or the serious negative social, cultural, and economic impacts on local communities.

Although current President Ivan Duque has called for "responsible development," the National Development Plan 2018-2022 introduced an expansion of the mining sector that has made the country one of the top extractive economies in Latin America. In order to achieve these goals, it was necessary to sell and/or concede significant territory to multinational companies, leading to an increased presence of large-scale mining operations. Some exploitation contracts with multinational companies involve protected areas. Mining projects are also planned in indigenous territories, such as a license to exploit 1,995 hectares by open-pit mining in the Great Indigenous Reservoir of Vaupés (Agenda Propia 2020).

History shows that there is no linear relation between conflict and mining, as conflict dynamics depend on the previous presence of the state, infrastructure, the type of mineral and extraction method, and the geostrategic importance of the jurisdiction for armed and criminal groups 
(Rettberg et al. 2020). It is clear, however, that mining intersects and interacts with violent conflict in numerous regions. This includes medium mining operations and artisanal mining areas where armed actors vie for territorial control for illegal mining or coca cultivation, and large-scale mining where protest is criminalized and community leaders are victimized.

\section{Surveying the church on extractives, governance, and peace}

In the midst of this national mining panorama, the social struggles for the protection of the territory, the life of the communities, and the biodiversity of the country have started to become more public. Several ecclesiastical jurisdictions began to request support to analyze and accompany the communities affected by extractive activities. In 2013, the Episcopal Conference of Colombia and Caritas Colombia conducted a semistructured baseline survey that examined the perceived effects of extractives in the jurisdictions. The study examined the existing relationships between the mining industry and the intensification of conflict, the exploitation and use of resources, the presence of illegal armed groups, and the displacement of communities. Seventy-four Catholic Church representatives participated. For the first time, a map of perceived effects of extractives in Colombia was available to the public. ${ }^{3}$

During the Colombian peace process (2012-2016), some hoped for dialogue about the role of extractives and peace, but the topic was avoided in order to achieve an agreement. Despite being one of the world's most comprehensive peace accords, the failure to address mining reflects a missed opportunity to connect integral peace, ecology, and development.

Given the need for reliable microdata showing how extractives were affecting the territories after the peace agreement, in 2020 Caritas Colombia developed a survey of representatives of the ecclesiastical jurisdictions in order to determine the main social, political, economic, cultural, and environmental impacts of extractives. This follow-up study improved on the 2013 survey in three ways. First, it allowed information to be collected and analyzed in real time, reducing the duration of data collection by $60 \%$. Second, three modules were added: social capital, forms of pastoral accompaniment, and sources of doctrinal support from the Catholic Church. Third, the results of the 2013 survey were adapted to a database that allowed comparisons with other databases and with the 2020 data (Polanía-Reyes 2021). The 2020 survey was conducted with 104 church representatives (archbishops, bishops, and social pastoral directors) and included each ecclesiastical jurisdiction.

The survey confirmed that the extraction of natural, mineral, or hydrocarbon resources is an unstoppable reality. It occurs in $92 \%$ of the country's jurisdictions. This is an increase of $11 \%$ since 2013 . There is also an increase in the perceived exploitation of iron ore, aggregates, nickel, limestone, coltan, and emeralds. When disaggregated at the sector level, most of 
the significant increase in extraction is for construction and industrial resources. Large-scale and artisanal exploitation constitute $68 \%$ of total extraction. In addition, the number of projects in an exploitation phase increased from $52 \%$ to $89 \%$. There is also a $78 \%$ increase in extraction in protected areas compared to 2013.

As of 2020 , there is no social engagement with the community in $49 \%$ of the extractives cases, and a high degree of engagement in only $8 \%$. In many of the protected natural areas, areas of indigenous reserves, and/ or collective territories of Afro-Colombians, companies do not follow the procedure of prior or popular consultation, violating a fundamental right of those communities. Despite the fact that the oil industry is a century old and oil generates the most income in the country, the industry has low levels of engagement with the communities and often breaches agreements. In total, companies have breached agreements in $58 \%$ of cases.

The survey found that the majority of mining communities have high rates of poverty and deterioration of the quality of life and the social fabric. Whether violence and conflict might explain this relationship is an open research question. Positive economic effects included revitalization of the local economy $(50 \%)$, an increase in employment $(49 \%)$, and enhancing local government revenues through taxes $(30 \%)$. Negative effects included shocks to the local economy $(62 \%)$, price increases $(60 \%)$, and the limiting or prohibition of traditional mining $(42 \%)$.

Perception of positive social effects deteriorated in 2020 compared to 2013. In $2020,58 \%$ of reported projects did not present any positive social impact. The remaining projects present stronger presence of national institutions $(20 \%)$ and defense manpower $(15 \%)$, signaling less crime and violence. Many negative social effects stand out: the arrival of foreigners $(76 \%)$, the privatization of natural resources $(74 \%)$, increase in false expectations generated by the companies to the communities $(70 \%)$, and different forms of violence $(67 \%)$. In $79 \%$ of reported projects there was some type of violence (i.e., threats, intimidation, and forced displacement) in the resistance processes.

When asked about perceived environmental and cultural effects of extractives in Colombia, $82 \%$ of the surveyed jurisdictions in 2020 affirmed that there are no positive environmental effects of mining, a significant increase of 77 percentage points compared to 2013. The main positive environmental effects are watershed conservation (24\%), reforestation $(12 \%)$, and recovery plans for damaged areas $(20 \%)$. The main negative environmental effects are pollution and/or deterioration of water sources $(78 \%)$, soil deterioration $(75 \%)$, and deforestation (78\%). Prevalent cultural effects of extractives are being uprooted from territories $(72 \%)$, a culture of waste $(63 \%)$, and acculturation and loss of traditions $(60 \%)$. Few projects had introduced programs for recovery of traditions of affected communities (17\%). 


\section{Analyzing the Catholic Church's action on mining, development, and peace: the emergence of an eco-theology of peace}

The Colombian Catholic Church, in compliance with its mission, works for reconciliation and unity, as well as to promote human dignity and the common good. Socially marginalized groups are the focus of the commitment to promote integral and sustainable development and work for justice and deeper reconciliation. The poor are the most affected by the conflicts caused by economic growth and social inequality, and the negative effects of mining on the environment. The church accompanies these communities, not only as a permanent presence in their midst but also to build on its history of struggling to build peace. Below we describe the implications of our study for the church's role in addressing mining issues in Colombia.

\section{Strategies within the church}

Although half of the jurisdictions partially agree that mining is necessary for the community, the Catholic Church is one of the leading organizations resisting mining. Leaders of community-based organizations and affected communities consider the Catholic Church a more trustworthy partner than academia or grassroots organizations. Of the many mining-related activities, church representatives are least likely to participate in political processes, but, when they do, the intensity of their participation is the highest. The next most intense levels of participation are teaching skills to local inhabitants and mediating between the government and the community. Clearly, the church in some jurisdictions is more active in accompaniment processes and could motivate other jurisdictions to do the same.

Our finding that mining operations have expanded in recent years to cover $90 \%$ of the territory challenges the Catholic community to consider how it might address this issue in a coordinated way in a larger number of local communities, as well as on a national and international level. The role of multinational corporations, foreign governments, and international institutions suggests the importance of coordinating with Catholic entities globally in addressing mining. At the local level, several strategies could be implemented, including (1) using the survey instrument as a pedagogical tool; (2) improving the space for interaction between government authorities and church leaders at the national level; and (3) providing training on extractive resources, mining impacts, accompaniment, and Catholic social teaching.

Our study helps address the lack of information on mining. While it might not be the role of the institutional Church to monitor such activities on an on-going basis, as is done in the Democratic Republic of the Congo, our study shows the need for Catholic and secular NGOs to develop or strengthen such monitoring as an essential first step in strengthening their 
capacity to engage effectively on mining issues. A communication portal on extractives at the jurisdiction level is necessary as it will provide local and national church leaders with vital information. This includes contact details of industry representatives and other mining actors, resources and data on extractives, a bank of documents on Catholic teaching related to the subject, and guidance on resistance processes and consultation or community engagement processes.

\section{Strategies alongside the most vulnerable}

The church's accompaniment involves recognizing the unity of community identity, culture, and territory. Mining-related conflicts rupture this unity. For example, the greatest victimizing event of the internal armed conflict in Colombia has been forced displacement - 7.5 million people have had to leave their territory. Mining modifies the lives of the local inhabitants, including their geographical environment and their customs. When those responsible for mining are unaware of or indifferent to such facts, new conflicts arise, existing conflicts are exacerbated, or latent conflicts intensify. Although an effective response must address the social and political structures of the country, the church is doing its best to help the urgent needs of the most vulnerable, as it does on a wide range of issues.

In order to reduce vulnerabilities and to prevent or reduce conflicts, the church must help communities take a constructive and proactive position towards their rights related to the environment and their territories. A multi-stakeholder dialogue requires training and accompaniment to build public spaces of dialogue and reciprocal listening. The main church activities in relation to extractives are (1) emotional, social, pastoral, and spiritual support; (2) presence at the base or directly serving the community affected by mining; and (3) advocating or working against the harmful effects of mining. In addition, the church trains community leaders and supports local peace initiatives that promote the collective construction of new relationships with the land and natural resources. The local church, Caritas, and the community can also collaborate in raising awareness of the situation for local, national, and international audiences. In addition, some pastoral work is directed towards government authorities and the private sector so that they effectively recognize the rights of the people and their obligation to comply with environmental protection provisions.

Communities in remote places and without employment options must deal with the dilemma of choosing between a system that guarantees daily sustenance and work in the short and medium term and preserving water sources and an environment conducive to agriculture and food security in the long term. A model of resource extraction that includes the well-being of the community and environment is possible to design and implement. It is an illusion to assume that there must be a trade-off between caring for the environment and mining-related development. Communities with mineral 
resources often ask themselves about their moral responsibility in caring for their environment. The church could help answer these questions. In particular, when communities are not consulted and face the challenge of caring for creation amidst violence by those who would harm the environment, pastoral care requires a pedagogy that helps the communities understand the theological meaning of creation, its universal destiny, and how to exercise their duty to protect the environment.

\section{Anthropological foundation of ecology}

We must not separate individual faith from collective care for creation, although for many people the former is not a prerequisite for the latter. An approach to ecology that stems from belief in God, the Creator, conceives the human person as the Imago Dei. Thus, a robust anthropology must be grounded in the value of human life. Respect for human life is a necessary condition for a coherent ecology.

In our study, we found that church representatives used similar principles of Catholic social thought to address the issues of extraction. Integral human development is used the most, followed by the common good and the promotion of peace. Surprisingly, stewardship of or care for creation were not noted in our survey. We also found that in $12 \%$ of cases respondents reported that they do not use any principles of the church's social doctrine. These results show the unfortunate separation between pastoral work and Catholic social teaching.

\section{Integration of creation and salvation}

The theology of salvation, a primary concern of the faithful, must be in dialogue with the theology of creation, which is neither well-known nor well-taught in many sectors of the church. A utilitarian approach to the goods of creation takes hold in the absence of a tangible sense of stewardship towards creation. Such a mentality endures when a faith that integrates the mystery of creation and the destiny of salvation is not cultivated. Integral and sustainable development and the principle of human dignity are in close relation to the call to care for creation (Francis 2015). Accompaniment for the Colombian Church needs to entail introducing these principles and responsible collaboration with the work of the Creator.

The National Social Pastoral aims to reconcile the focus on integral, solidaristic, and sustainable human development among church leaders with the principle of care for creation. The papal magisterium has advanced reflection on this throughout the last decades, especially recently with Pope Francis's encyclicals, Evangelii Gaudium and Laudato Si', and his postsynodal apostolic exhortation, Querida Amazonia. The Latin American Episcopal Council has devoted much reflection to this topic and made calls 


\section{Sandra Polanía-Reyes \& Héctor Fabio Henao}

for ecological awareness and care for creation (see CELAM 2018). In our study, the three most important resources of Catholic social teaching that are used in the accompaniment of communities in the jurisdictions in relation to extraction are Laudato Si, the Compendium of the Social Doctrine of the Church, and the Bible.

\section{Reconciliation and unity}

Strengthening the relationship between peacebuilding and extractive activities allows a more constructive path for transforming conflict. Many cases in Colombia show the difficulties that people have in reestablishing neighborly relations and ensuring communal belonging after conflict subsides. It takes time to reconstruct an altered or destroyed social fabric. Pastoral action must consider that mining affects people's lives and puts them in very complex situations. Mining creates stress in personal lives and changes in the family structure and in the organization of communities. To speak about how to reconstruct the social fabric from a theological and pastoral perspective leads us to a deep reflection on the path traveled by the apostles and the nascent community after the resurrection and ascension of the Lord. The good was taken away and the better was coming with Pentecost. Those are the keys to accompany the community in the midst of bewilderment and numerous losses, including land, community relations, and its primary roots.

There is a permanent goal in pastoral work: to maintain hope. Hope is present in pastoral care as a deep, non-destructive relationship, one that is transformative and bears responsibility for the environment. In constructing peace in the context of environmental conflicts, which are often associated with mining, we have learned that we must not forget that hope is closely linked with harmony in the relationship between the inhabitants and the environment. This implies that working towards peace requires introducing a key ethical criterion: the care of creation. This element goes beyond the interaction between groups with conflicting or diverse interests, the intervention of the state, or the market. We cannot think of conflicts without recognizing that creation and its destiny are at stake. Not acknowledging creation or treating it in a simply instrumental way only deepens conflict and makes it much more complex in its different dimensions.

Peace requires a truly communitarian attitude. The church continues to promote open and transparent dialogue between different actors in society who are involved in socio-environmental conflicts. Experiences in Colombia show that when communities act as a whole and in a coordinated way, placing the common good above particular interests, they create new alternatives and perspectives to undertake the challenges faced in their territory. Pastoral experience shows that following this path helps to create links with government authorities and with other 
organizations interested in mining. The result is an integrated response to the problem, a community open to dialogue, which incorporates new perspectives and ways of seeing reality. Pope Francis teaches that unity prevails over conflict, but that requires that we carefully consider the impact on communities of conflict and alterations of their territory. By strengthening the cohesion of the community, recovering the sense of community, and constructing agreements that enable dialogue and advocacy with those responsible for political and social decisions, the "culture of encounter" is regained and strengthened.

\section{Notes}

1 This paper is based on a study conducted by Sandra Polanía-Reyes in collaboration with the Colombian Catholic bishops' National Social Pastoral and Caritas Colombia, directed by Msgr. Héctor Fabio Henao. We thank the Catholic Peacebuilding Network (CPN), based at the University of Notre Dame's Kroc Institute for International Peace Studies in the Keough School of Global Affairs, for financial support. The opinions expressed in this manuscript are the exclusive responsibility of the authors, and may not coincide with those of the National Social Pastoral, Caritas Colombia, or CPN.

2 For example, Instituto de Estudios para el Desarollo y la Paz (2019) reported that 566 killings occurred between January 2016 and January 2019 alone, and Cuartas's (2021) amicus brief for Human Rights Watch acknowledges that Colombia's Human Rights Ombudsperson's Office reports over 700 killings between 2016 and 2021.

3 See https://impactoindustriasextractivas.caritascolombiana.org/.

\section{References}

Agenda Propia. 2020. “Defensores de los cerros sagrados.” January 2020. https:// www.agendapropia.co/defensores-de-los-cerros-sagrados/\#Inicio-lxms8KjhGG.

Alliance for Responsible Mining. 2014. "Update from Oro Verde and AMICHOCO.” May 14, 2014. https://www.responsiblemines.org/en/2014/05/updatefrom-oro-verde-and-amichoco/.

Colombian Ministry of Foreign Affairs. 2021. "Distribución de Venezolanos en Colombia-Corte 31 de Enero de 2021." March 3, 2021. https:// www.migracioncolombia.gov.co/infografias/distribucion-de-venezolanos-encolombia-corte-31-de-enero-de-2021.

CELAM (Consejo Episcopal Latinoamericano). 2018. Discípulos Misioneros: Custodios de Nuestro Hogar Común: Discernimiento a la Luz de la Encíclica Laudato Si'. Bogotá: Consejo Episcopal Latinoamericano, CELAM.

Cuartas, José Fernando Reyes. 2021. "Amicus Brief on Killings of Human Rights Defenders in Colombia.” Human Rights Watch. April 20, 2021. https:// www.hrw.org/news/2021/04/20/amicus-brief-killings-human-rights-defenderscolombia\#_ftn1.

Francis. 2015. Laudato Si'. https://www.vatican.va/content/francesco/en/encyclicals/ documents/papa-francesco_20150524_enciclica-laudato-si.html. 


\section{Sandra Polanía-Reyes \& Héctor Fabio Henao}

Instituto de Estudios para el Desarollo y la Paz. 2019. "566 líderes sociales y defensores de derechos humanos han sido asesinados desde el 1 de enero de 2016-Al 10 de enero de 2019.” January 11, 2019. http://www.indepaz.org.co/ 566-lideres-sociales-y-defensores-de-derechos-humanos-han-sido-asesinadosdesde-el-2016-al-10-de-enero-de-2019/.

Peace Accords Matrix Barometer Initiative/Kroc Institute for International Peace Studies. 2021. Executive Summary, The Colombian Final Agreement in the Era of COVID-19: Institutional and Citizen Ownership is Key to Implementation. Notre Dame, IN and Bogotá, Colombia: Peace Accords Matrix Barometer Initiative/Kroc Institute for International Peace Studies/Keough School of Global Affairs. 10.7274/r0-cffp-qr07.

Polanía-Reyes, Sandra. 2021. "The Catholic Church and Extractive Activities in Post-Conflict Colombia: A Survey Follow-up to the Ecclesiastical Jurisdictions.” Technical Report. Catholic Peacebuilding Network and Caritas Colombia (forthcoming).

Rettberg, Angelika, Carlo Nasi, Ralf J. Leiteritz, and Juan Diego Prieto Sanabria. 2020. Different Resources, Different Conflicts? The Subnational Political Economy of Armed Conflict and Crime in Colombia. Bogotá: Universidad de los Andes. https://www.jstor.org/stable/10.7440/j.ctv11vcd7n.

UN Human Rights Council. 2019. "Visit to Colombia: Report of the Special Rapporteur on the situation of human rights defenders." A/HRC/43/51/Add.1. December 26, 2019. https://undocs.org/en/A/HRC/43/51/Add.1. 